\title{
HVORDAN ØKE ARTIKKELENS
}

Optimalisering av artikler for søkemotorer.

Mange studenter og forskere leter etter informasjon på nettet ved hjelp av søkemotorer, for eksempel Google. Når du jobber med artikkelmanuskripter kan du ved å gjøre tilpasninger optimalisere sjansen for at interesserte lesere finner den. Fagerbergutvalget lanserte siteringsindeks som et kriterium for forskningens gjennomslagskraft. Det er derfor grunn til å tro at det kommer til å bli mer fokus på hvor ofte artikler er sitert av andre forskere i fremtiden. Ved å gjøre artikkelen lettere søkbar for andre vil også sannsynligheten for at den blir sitert i et annet verk $\varnothing$ ke. Flere tidsskrift har utarbeidet veiledninger til forskere som ønsker å $\varnothing k e$ sjansen for at andre finner den på nettet ved hjelp av søkemotorer. Formulering av tittel på artikkelen og sammendraget er trolig de to viktigste forholdene som er av betydning for at andre finner artikkelen.

\section{HVORDAN FUNGERER SøKEMOTORENE?}

De ulike søkemotorene har egne algoritmer for rangering av innhold og dermed treff. Hvordan algoritmene er bygget opp i de ulike søkemotorene er vanligvis en bedriftshemmelighet. Mye av kunnskapen vi har om optimalisering av søk er derfor knyttet til erfaring og kunnskap ut fra hvordan søkemotorer fungerer generelt. Dette gjelder blant annet artikler. Mange søkemotorer fanger opp relevans og popularitet ved å koble innholdet til andre nettsteder, for eksempel Facebook og Twitter. Stoff som har mange «likes» fanges derfor lettere opp av søkemotorer. Søkemotorene fors øker å finne temaet man søker på ved hjelp av å finne deler. En slik del kan søkemotoren finne i en såkalt metadata tag. Denne taggen ligger usynlig for brukeren, men er med på å vurdere om innholdet er relevant eller ikke. Søkemotorer kan også scanne en side for søkeord eller setninger. Hvis ordene finnes i overskriften og eller forekommer gjentakende ganger i fraser i teksten, øker dette muligheten for treff.

\section{TITTELEN ER VIKTIG}

$\AA$ lage en klar beskrivende tittel er et av de viktigste rådene man kan gi for å øke søkbarheten. Søkemotorer rangerer generelt titler veldig høyt. Søkemotorer antar generelt at ordene i tittelen dekker det sentrale innholdet i artikkelen. Tar du utgangspunkt i søkemotoren, finnes definisjonen til artikkelens innhold i ordene som er brukt i tittelen. Dette er grunnen til at en nøyaktig tittel, hvor de mest relevante begrepene er brukt, er så viktig for at artikkelen skal bli funnet. Når du utarbeider tittelen kan det være lurt å sette seg i leseres sted å tenke på hvilke begrep det er sannsynlig at leseren vil bruke for å lete etter artikkelen. Begrepene du da kommer frem til bør du prøve å benytte i tittelen. Mange forfattere velger å bruke begreper i tittelen av mer skjønnlitterær karakter, eller begreper med dobbelt betydning der den doble betydningen henspiller på artikkelens innhold. Dette kan medføre langt færre treff i søkemotorer.

\section{GJENTA VIKTIGE ORD ELLER FRASER}

Nest etter tittelen, er innholdet i sammendraget viktig. Hvis begrepene leseren bruker i søkene forekommer i tittelen på en artikkel, kan det øke sjansen for treff hvis de er gjentatt i sammendraget. Dette bør imidlertid ikke overdrives. Unødige gjentakelser kan føre til at siden avvises av søkemotorer.

\section{ET EKSEMPEL}

Eksempel på et kjent begrep er «Samhandlingsreformen». Hvis en leser er ute etter stoff på dette temaet, er det naturlig at vedkommende søker på dette begrepet. Forekommer begrepet både i tittel og sammendrag, øker sjansen for at artikkelen vil komme høyt opp på søkemotorens treffliste. Hvis forfatteren velger ikke å bruke dette begrepet, men heller «den nye reformen for samhandling» kan dette redusere muligheten for å bli funnet gjennom søkemotorene. Hvis forfatteren for samme artikkel velger å gi artikkelen en litterær, mer kreativ tittel som for eksempel: 


\section{SøKBARHET?}

«Det som blir er ikke som det var», vil dette trolig innebære at lesere ikke vil finne artikkelen når det søkes gjennom søkemotorer.

\section{VIKTIGE TIPS:}

- Tenk på hvilke begrep en potensiell leser vil bruke for å finne artikkelen din

- Sørg for at tittelen inneholder de viktigste begrepene som beskriver innholdet

- Sentrale begreper og/eller fraser bør gi mening og flyt i tittel og sammendrag

- Det kan være lurt å bruke tre-fire sentrale begrep i sammendraget i stedet for å krydre med mange for å vise forskjellige fasetter ved det samme

- Pass på at det er flyt i språket i sammendraget. Det er først og fremst laget for leseren og ikke for roboter - søkemotorer

\section{REFERANSER}

Wiley-Blackwell. Optimizing your article for search engines. 2011 http://authorservices.wiley.com/bauthor/seo.asp (23.05.2011). 